\title{
El principio de objetividad en el empleo público II: la objetividad como deber de los empleados públicos
}

\author{
M. ${ }^{a}$ Antonia Arias Martínez \\ Profesora Titular de Universidad \\ Universidade de Vigo \\ tona.arias@uvigo.es
} \begin{abstract}
La Constitución Española exige a la Administración pública y al personal que la integra un comportamiento objetivo, imparcial y neutral en el servicio al interés general. Pues bien, en este trabajo nos ocupamos, en primer término, de analizar en profundidad el deber de objetividad, imparcialidad y neutralidad de los empleados públicos conforme a las previsiones contenidas en el Código de Conducta integrado en el Estatuto Básico del Empleado Público. $Y$, en segundo lugar, se examina el sistema de garantías previsto en la legislación vigente con el fin de proteger la realización efectiva de las funciones encomendadas a los empleados públicos conforme al citado deber de objetividad.
\end{abstract}

Palabras clave Empleado público, objetividad, imparcialidad, neutralidad, incompatibilidades, régimen disciplinario.

\section{The principle of objectivity in public employment: objectivity as a duty of public employees}

\begin{abstract}
According to the Spanish Constitution, it is mandatory that the public administration and staff that integrates it behave in an objective, impartial and neutral way when serving the public interest. This study undertakes, first, an in-depth analysis of the duty of objectivity, impartiality and neutrality of public employees, subject to the provisions contained in the Code of Conduct integrated into the Civil Service Basic Statute. Secondly, this paper examines the system of guarantees provided for in current legislation in an attempt to warrant the actual implementation of the tasks entrusted to public employees in accordance with that duty of objectivity.
\end{abstract}

Key words

Public employee, objectivity, impartiality, neutrality, incompatibility, discipline. 


\section{INTRODUCCIÓN: BREVE ESBOZO DEL DEBER CONSTITUCIONAL DE OBJETIVIDAD DE LA ADMINISTRACIÓN PÚBLICA}

La Constitución Española de 1978 (en adelante CE) consagra, en su artículo 103 apartado primero, la objetividad como una nota esencial de la Administración Públi$\mathrm{ca}^{1}$. Se incardina así la objetividad, no sólo en el perfil ético² sino también jurídico de la institución administrativa³.

Estamos ante una regla de conducta que lleva a que las actuaciones de la Administración sean las más justas $y$, por tanto, ajenas a influencias de intereses partidistas que en ningún caso deben influir en las actividades de aquella. Ahora bien, desde el momento en que el estándar ético de la objetividad se incorpora al derecho positivo, una actuación carente de objetividad no queda en una mera transgresión ética sino que constituye, además, una conducta antijurídica 4 .

Es cierto que puede parecer redundante la declaración constitucional de objetividad de la Administración en el servicio a los intereses generales contenida en el art. 103.1 CE, ya que la actuación objetiva es algo intrínseco a la idea de servicio. No obstante, entendemos con la doctrina más autorizada, que esta afirmación es útil en cuanto que refuerza la idea de servicio de la Administración "a los intereses generales" y no al Gobierno5 lo que, a su vez, conecta con el principio de la neutralidad política de aquella frente a este.

Hay que tener en cuenta que, según del Diccionario de la Real Academia Española, objetividad significa "perteneciente o relativo al objeto en sí y no a nuestro modo de pensar o de sentir". Lo cual implica una actuación "desinteresada”, esto es, al margen de consideraciones o preferencias personales. En consecuencia, la objetividad administrativa implica una postura personal o institucional opuesta a cualquier tipo de subjetivismo. Es decir, una constatación y valoración del supuesto ajena a toda consideración personal.

1 A. Nieto ("La Administración sirve con objetividad los intereses generales", Estudios sobre la Constitución Española. Homenaje al Profesor Eduardo García de Enterría, Tomo III, Madrid:civitas, 1991, p. 2227) señala que ya Max Weber en su Economia y Sociedad había puesto de relieve que la objetividad era una carácteristica esencial de toda organización burocrática por lo que considera el autor que en este punto la CE no puede ser aparantemente más conservadora y tradicional.

2 L. Morell Ocaña ("La objetividad de la Administración Pública y otros componentes de la ética de la institución”, REDA, n. ${ }^{\circ}$ 111, 2001, pp. 348-349) no es la ética una exclusiva cuestión personal sino que también es exigible la ética institucional y, en el caso concreto de la Administración Pública, esta exigencia se deriva de la función que la Constitución le encomienda, esto es, el servicio a los intereses generales con plena sumisión a la Ley y al Derecho.

3 Como es sabido, el citado principio constitucional de objetidad de la Administración Pública ha sido posteriormente sancionado en normas administrativas de alcance general como la Ley 30/1992 de Régimen Jurídico de las Administraciones Públicas y del Procedimiento Administrativo Común en cuyo artículo tercero consagra de forma expresa el citado principio.

4 Morell Ocaña, L., “La objetividad de la Administración Pública y otros componentes de la ética de la institución”, op. cit., p. 358.

5 Nieto, A., “La Administración sirve con objetividad los intereses generales”, op. cit., p. 2228. 
Desde esta perspectiva, hay que tener en cuenta que la objetividad que se predica de la Administración transciende a los elementos personales de la organización administrativa, esto es, los empleados públicos que son los que, en definitiva, actúan en nombre de la Administración. Por ello la CE en su art. 103.3 determina la necesaria regulación por ley de las garantías para la imparcialidad del funcionario en el ejercicio de sus funciones. La objetividad que se predica de la Administración exige la actuación imparcial de los empleados públicos de modo que estos al interpretar y/o aplicar una norma, o ejercitar una potestad, deben realizar una valoración del supuesto concreto al margen de cualquier subjetividad o consideración personal ${ }^{6}$. Se anula el interés propio y particular del agente en aras a acatar la estricta voluntad de la norma?.

Por lo tanto, al actuar la Administración a través de las personas que la integran, la objetividad que se predica de aquella es, como manifiesta Morell Ocaña una consecuencia de la imparcialidad con que el funcionario actúe ${ }^{8}$. Para el autor citado, la conexión entre objetividad e imparcialidad es la de la relación causa-efecto: cuando la autoridad o funcionario actúa con imparcilidad, el resultado será la objetividad de la Administración? . Todo ello nos permite confirmar la distinción implícita que el Texto Constitucional realiza entre la noción de objetividad de la Administración (art. 103.1CE) y el concepto de imparcialidad del funcionario (art. 103.3CE).

Además, el empleado público, en atención al citado principio de neutralidad derivado también de la objetividad administrativa, debe realizar sus funciones con fidelidad institucional al Gobierno ${ }^{10}$. Es decir, con su actuación no puede contradecir las directrices de este pero sí realizar una interpretación de las mismas acorde con el interés general. En definitiva, no puede obstaculizar el desarrollo del programa gubernativo en atención a su propia ideología política y, además, debe, en aras a dicho principio, actuar sin favoritismos ni discriminaciones ${ }^{11}$. Se configura así, la neutralidad del empleado público, como otra vertiente del deber de objetividad de la Administración.

6 En este sentido L. Morell Ocaña (“La objetividad de la Administración Pública y otros componentes de la ética de la institución”, op. cit, p. 364) sostiene que “la imparcialidad -en cuanto cualidad de la conducta de los agentes administrativos- encuentra su esencia en el modo como se han de entender $y$ aplicar las normas. Exige, en este sentido, una fidelidad a la voluntad plasmada en la regla de derecho, en su interpretación y ejecución; fidelidad que implica la renuncia a toda interpretación lograda desde el subjetivo querer y opinión del que actúa".

7 Es esta una interpretación conforme al significado atribuido al vocablo "imparcialidad” por el Diccionario de la Real Academia Española (Ed. 21. ${ }^{a}$, Madrid: Espasa Calpe): falta de designio anticipado o de prevención a favor o en contra de personas o cosas, que permite juzgar o proceder con rectitud.

8 Morell Ocaña, L., "La objetividad de la Administración Pública y otros componentes de la ética de la institución”, op. cit., p. 363. En el mismo sentido, Carro Fernández Valmayor, J.L., “Ética pública y normativa administrativa", Revista de Administración Pública, n. ${ }^{\circ}$ 181, 2010, pp. 9-37.

9 Morell Ocaña, L., "La objetividad de la Administración Pública y otros componentes de la ética de la institución”, op. cit., p. 363.

10 Estamos ante lo que el Profesor F. Garrido Falla (Comentarios a la Constitución, 2. Ed., Madrid:civitas, 1985, p. 1425) ha denominado “eficacia indiferente”. La neutralidad exige al agente público, eficacia "tanto si perjudica como si favorece la política del gobierno que está en el poder".

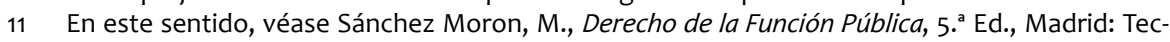
nos, 2008, p. 279. 
En definitiva, existe una estrecha relación entre los conceptos de objetividad, imparcialidad y neutralidad, predicándose el primero de la Administración, y referidos los segundos a la forma de proceder en sus actuaciones el personal al servicio de aquella. No obstante, veremos que la normativa vigente utiliza dichos conceptos de forma indistinta para referirse tanto a la actuación de la Administración pública como a la de sus empleados.

Una manifestación clara de lo antedicho, es la actual Ley 7/2007, de 12 de abril, del Estatuto Básico del Empleo Público (en adelante EBEP) que establece un código de conducta de los empleados públicos en los que se definen sus deberes y los principios a los que deberán sujetar su actuación. Entre estos, el EBEP, hace referencia de forma expresa al de objetividad, neutralidad e imparcialidad del personal a su servicio.

Con el fin de proceder al análisis de "la objetividad como deber de los empleados públicos", título del presente trabajo, comenzaremos, en primer lugar, realizando una breve exposición de la regulación que, con carácter general, realiza el EBEP de los deberes de los empleados públicos. La cuestión central de este apartado es la evaluación de la operatividad real de los deberes que integran el denominado Código de Conducta.

Este análisis previo nos prepara para descender al estudio del concreto deber de "objetividad" de los empleados públicos en el ejercicio de sus funciones. Ello exige, en primer término, un análisis detallado de los distintos apartados que conforman los artículos 52, 53 y 54 integrantes del Capítulo VI del Título III ("Derechos y deberes. Código de Conducta de los empleados públicos") del EBEP y que, como veremos, aluden, directa o indirectamente, al deber de objetividad, imparcialidad y neutralidad de los empleados públicos.

No obstante, de nada sirve establecer una relación de deberes y principios de actuación de los servidores públicos sino se diseña un sistema de garantías que trate de asegurar su cumplimiento y, en consecuencia, que determine los efectos negativos que lleva aparejada su inobservancia. Por ello, el trabajo se cierra con la realización de un breve comentario sobre el sistema de garantías previsto en la legislación vigente con el fin de proteger la realización efectiva de las funciones encomendadas a los empleados públicos conforme al deber de objetividad.

\section{LA OBJETIVIDAD COMO DEBER DE LOS EMPLEADOS PÚBLICOS}

\subsection{Los deberes de los empleados públicos en la normativa básica del empleo público}

La Ley de Funcionarios Civiles del Estado de 1964 (LFCE) establecía en la Sección primera de su Capítulo VII (arts. 76 a 81) bajo la rúbrica "Deberes e incompatibilidades" una escueta relación de los deberes de los funcionarios públicos. Un lis186 tado de obligaciones que ha sido calificado, con total acierto a nuestro juicio, de 
incompleto ${ }^{12}$ y claramente deficitario ${ }^{13}$ y que, en consecuencia, había de ser completado por la vía del régimen disciplinario previsto ${ }^{14}$. Esta escasa regulación choca con la mas detallada ordenación de sus derechos a los que la citada norma dedica el Capítulo VI integrado por los artículos 63 a 75. La diferencia de trato, no sólo cuantitativa sino también cualitativa, en la reglamentación histórica de los derechos y deberes de los funcionarios se ha debido a la mayor preocupación de dicha legislación por tutelar la posición jurídica individual del funcionario público que por garantizar las obligaciones del servicio's.

El cambio de cultura administrativa guiada por el principio básico de dar satisfación a los intereses generales y, en consecuencia, gestionar los servicios en beneficio del ciudadano de acuerdo con las reglas constitucionales, de eficacia, jerarquía, e imparcialidad, entre otras, ha incitado al legislador a realizar cambios legislativos en la regulación de los deberes de los funcionarios públicos.

Asimismo, era necesraio equiparar las obligaciones de aquellos que sirven en la misma organización aunque su régimen jurídico no sea idéntico. Los mismos deberes básicos deben ser aplicables a los contratados en régimen laboral y a los funcionarios públicos de la Administración y Entidades Públicas ya que quienes sirven en la misma organización y realizan funciones equiparables no pueden, por principio, sujetarse a deberes básicos diferentes"16.

Todo ello ha llevado al legislador a introducir en EBEP lo que ha denominado Código de Conducta aplicable a todos los empleados del sector público ${ }^{17}$ incluyendo a los trabajadores de las entidades del sector público que no están comprendidas en el ámbito de aplicación del EBEP18, esto es, el personal de las sociedades mercantiles y fundaciones del sector público ${ }^{19}$.

12 Véase en este sentido a Castillo Blanco, A. y J. E. Quesada Lumbreras "Deberes de los empleados públicos. Código de Conducta”, Comentarios a la Ley 7/2007, de 12 de abril, del Estatuto Básico del Empleado Público, dir. A. Palomar Olmeda y A.V. Sempere Navarro, Aranzadi, 2008, p. 456.

13 En este sentido Sánchez Morón, M., Derecho de la Función Pública, op. cit., p. 275.

14 En este sentido J.A. Santamaría Pastor (Principios de Derecho Administrativo, vol. I, Madrid: Centro de Estudios Ramón Areces, $2 .^{a}$ Ed, 1998, p. 656) señala que de la obligación básica prevista en el art. 76 LFCE se pueden deducir múltiples conductas debidas. Algunas de ellas son mencionadas expresamente por la LFCE, y otras "se deducen por vía negativa de la enumeración de conductas que constituyen faltas disciplinarias". Pero ni una ni otra relación puede considerarse exhaustiva.

15 Así lo señala el Informe de la Comisión para el estudio y preparación del Estatuto Básico del Empleado Público, Madrid: INAP, 2005, p. 200.

16 Informe de la Comisión para el estudio y preparación del Estatuto Básico del Empleado Público, p. 202.

17 Con carácter previo se aprobó la Ley 5/2006, de 10 de abril, de regulación de los conflictos de intereses de los miembros del Gobierno y de los Altos Cargos de la Administración General del Estado y el Código de Buen Gobierno de los miembros del Gobierno y de los altos cargos de la Administración General del Estado, aprobado por Acuerdo del Consejo de Ministros de 18 de febrero de 2005. El fin perseguido por ambos instrumentos normativos era enmarcar la actuación de los miembros del gobierno y altos cargos en parámetros éticos recogidos en normas jurídicas.

18 De acuerdo con la Disposición Adicional primera del EBEP “Los principios contenidos en los artículos 52, 53, 54, 55 y 59 serán de aplicación en las entidades del sector público estatal, autonómico y local, que no estén incluidas en el artículo 2 del presente Estatuto y que estén definidas así en su normativa específica".

19 Por lo que se refiere al personal al servicio de la Sociedad Estatal de Correos y Telégrafos, de acuerdo con el art. 5 del EBEP, mientras que su personal funcionario se regirá por sus normas específicas y 
La solución adoptada no se ajusta totalmente a la propuesta formulada, en su día, por la Comisión para el estudio y preparación del EBEP. Esta Comisión sostiene que en el ámbito del empleo público las soluciones adoptadas en algunos países con una tradición jurídica muy distinta a la nuestra ha sido la codificación de los principios éticos como un catálogo de deberes deontológicos, objeto de sistemas de autocontrol o de control corporativo o asociativo ${ }^{20}$. Sin embargo, en países como el nuestro, la Comisión afirma que "dichos principios éticos se hacen presentes a través de la regulación legal de los deberes y obligaciones de los empleados públicos, cuya inobservancia tiene, por lo general, efectos disciplinarios"21.

Pues bien, el EBEP dedica su Capítulo VI conformado por los artículos 52, 53 y 54 a la regulación de los “Deberes de los empleados públicos. Código de Conducta”. En estos tres artículos se hace alusión a tres aspectos no fácilmente separables y diferenciables. En el primero de los preceptos citados (art. 52) se refiere, según figura textualmente en su rúbrica, a "los deberes de los empleados públicos" con el subtítulo de "Código de Conducta". Conforme al tenor literal de este precepto parece que el deber fundamental en el que podríamos integrar a todos los demás es el de "desempeñar con diligencia las tareas que tengan asignadas y velar por los intereses generales con sujección y observancia de la Constitución y del resto del ordenamiento jurídico". En este mismo precepto enuncia, posteriomente, hasta quince principios de actuación ${ }^{22}$ estrechamente relacionados entre sí, llegando, incluso, a ser difícil establecer diferencias entre ellos ${ }^{23}$. Principios que, según el citado artículo 52, inspiran el Código de Conducta de los empleados públicos integrado por los principios éticos ${ }^{24} \mathrm{y}$

supletoriamente por lo dispuesto en este Estatuto, su personal laboral se regirá por la legislación laboral y demás normas convencionalmente aplicables.

20 En este sentido F.A. Castillo Blanco ("Los deberes de los funcionarios públicos”, Comentarios a la Ley del Estatuto Básico del Empleado Público, 2. ${ }^{a}$ Ed., dir. M. Sánchez Morón, Lex Nova, 2008, pp. 394 y ss.) señala que en numerosos paises con el fin de conseguir el mejor servicio a los ciudadanos y la generación de confianza en la integridad y eficacia de las Administraciones Públicas ha impulsado a establecer en el sector público principios de ética y de conducta de éste. Entiende el autor que el buen funcionamiento de las organizaciones que integran el sector público etatal representa un factor de competitividad clave en toda sociedad moderna que permite garantizar el bienestar de los ciudadanos y un correcto desenvolvimiento de las Empresas y de las Instituciones. Así estos Códigos han visto la luz en la Unión Europea, los EEUU, la OCDE, el Reino Unido y Portugal, entre otros.

21 Informe de la Comisión para el estudio y preparación del Estatuto Básico del Empleado Público, p. 201.

22 Objetividad, integridad, neutralidad, responsabilidad, imparcialidad, confidencialidad, dedicación al srevicio público, transparencia, ejemplaridad, austeridad, accesibilidad, eficacia, honradez, promoción del entorno cultural y medioambiental y respeto a la igualdad entre mujeres y hombres.

23 Son principios que, como pone de manifiesto L. Martín Rebollo (Leyes Administrativas, 17 Ed., Aranzadi, 2011, p. 1596), no es siempre fácil distinguir entre ellos y podría cuestionarse la ubicación y hasta la pertinencia de algunos. Así, por ejemplo, la objetividad y la imparcialidad a veces se solapan o cuando menos no está tan claro el distingo, como tampoco lo está la distinción entre esos dos conceptos y el de neutralidad. Por lo que se refiere al orden de enumeración, llama la atención, como señala el citado autor, que la eficacia figure en el duodécimo lugar cuando es el primer principio que informa la actividad de la Administración según el texto constitucional (art. 103). Finalmente, por lo que se refiere a la oportunidad de otros principios como la promoción del entorno cultural y medioambiente sólo indirectamente cabe calificar como deberes y no se sabe muy bien cómo afectan a los empleados públicos.

24 Tales principios son respetar la Constitución, los estatutos de autonomía y el resto del ordenamiento jurídico; perseguir la satisfacción de los intereses generales al margen de cualquier otro factor que 
de conducta ${ }^{25}$ regulados en los artículos siguientes, entiéndase respectivamente, el 53 y 54 del EBEP.

Una buena parte de la doctrina, tanto laboralista ${ }^{26}$ como administrativista $^{27}$, se han hecho eco de la deficiente factura técnica (reiteraciones, no se sabe porque unos

exprese posiciones personales, familiares, corporativas, clientelares o cualesquiera otras que puedan colisionar con este principio; ajustar su actuación a los principios de lealtad y buena fe con la Administración y sus superiores, compañeros, subordinados y ciudadanos; respetar los derechos fundamentales y libertades públicas actuando sin incurrir en discriminación; abstenerse en aquellos asuntos que tengan interés personal; no contraer obligaciones económicas in intervenir en operaciones financieras o patrimoniales, cuando pueda suponer un conflicto de intereses con las obligaciones asumidas en un puesto público; no aceptar tratos de favor que implique privilegio o ventaja injustificada por parte de las personas físicas o entidades privadas; actuar con arreglo a los principios de eficacia, economía y eficiencia; no influir en agilización o resolución de trámites o procedimientos a favor de los titulares de los cargos públicos o su entorno familiar social en menoscabo de terceros; cumplir con diligencia las tareas encomendadas y resolver los expedientes dentro del plazo; ejercer sus atribuciones según el principio de dedicación al servicio, absteniéndose de conductas que comprometan la neutralidad en el ejercicio de los servicios públicos; guardar secreto de las materias clasificadas de difusión prohibida y mantener la discreción sobre aquellos asuntos que conozcan por razón de su cargo sin hacer uso en beneficio propio o de terceros, o perjuicio del interés público.

25 De acuerdo con estos principios tratarán con atención y respeto a los ciudadanos, a sus superiores y a los restantes empleados públicos; desempeñarán su trabajo de forma diligente en la jornada y horario establecidos; obedecerán las instrucciones y órdenes profesionales de los superiores, salvo que constituyan una infracción manifiesta del ordenamiento jurídico, en cuyo caso las pondrán inmediatamente en conocimiento de los órganos de inspección procedentes; informarán a los ciudadanos sobre aquellas materias o asuntos que tengan derecho a conocer, y facilitarán el ejercicio de sus derechos y el cumplimiento de sus obligaciones; administrarán los recursos y bienes públicos con austeridad, y no utilizarán los mismos en provecho propio o de personas allegadas, y deberán velar por su conservación; rechazarán cualquier regalo, favor o servicio en condiciones ventajosas que vaya más allá de los usos habituales, sociales y de cortesía, sin perjuicio de los establecido en el Código Penal; garantizarán la constancia y la permanencia de los documentos para su transmisión y entrega a sus posteriores responsables; mantendrán actualizada su formación y cualificación; observarán las norms sobre seguridad y salud laboral; pondrán en conocimiento de sus superiores o de los órganos competentes propuestas para mejorar el desarrollo de las funciones de su unidad y, en fin, garantizarán la atención al ciudadano en la lengua que lo solicite siempre que sea oficial en el territorio.

26 J. Gárate Castro (“Art. 52. Deberes de los empleados públicos. Código de Conducta”, El Estatuto Básico del Empleado Público. Comentario sistemático de la Ley 7/2007, de 12 de abril de 2008, dir. J.L. Monereo Pérez et al, Granada: Comares, 2008, p. 498) al hacer referencia a la regulación contenida en los artículos 52, 53 y 54 del EBEP afirma que "se trata de reglas donde aparecen entremezclados, y hasta confundidos, en una especie de tótum revólutum y empleando una redacción penosa, deberes, conductas en que se manifiestan o concretan y principios o, mejor, valores que inspiran o a los que responden tales deberes y conductas". También J.M. Miranda Boto (“Art. 54. Principios de conducta”, El Estatuto Básico del Empleado Público. Comentario sistemático de la Ley 7/2007, de 12 de abril de 2008, dir. J.L. Monereo Pérez et al, Granada: Comares, 2008, p. 532) entiende que es una tarea ardua señalar diferencias claras y precisas entre la sustancia de lo recogido en el art. 54 y lo regulado en los artículos 52 y 53.

27 J.L. Carro Fernández Valmayor (“Ética pública y normativa administrativa”, op. cit., p. 21), critica el carácter desordenado y asistemático del mismo. R. Parada Vázquez (Derecho Administrativo Il. Organización y Empleo Público. Ed. 21, Madrid: Marcial Pons, 2010, p. 543) tras describir el contenido de los artículos 52, 53 y 54 del EBEP sostiene que es “desgraciadamente inverosímil que toda esta prolija, grandilocuente, confusa y repetitiva enumeración de enunciados morales pueda llegar a producir un efecto motivador significativo, supuesto que en estos tiempos los funcionarios pasan de sermones pedagógicos". M. Sánchez Morón (Derecho de la Función Pública, op. cit., p. 276) se refiere al contenido de este Capítulo VI del EBEP afirmando que se compone de una serie de principios y reglas, confusamente articuladas y, en algunos casos, reiterativas. Hace también alusión a las deficiencias técnicas ya que no está claro por qué ciertos "principios" se denominan "éticos" (art. 53) y otros de "conducta" (art. 54) y cual es la diferencia entre ellos, o por qué la mención al deber de diligencia aparece en los tres preceptos que componen el Código. 
principios se califican de éticos y otros de conducta, en qué se diferencian, etc.) de este Capítulo VI dedicado a los deberes de los empleados públicos.

No obstante, lo más relevante es determinar la operatividad de estos preceptos. Esto es, valorar si estamos ante conductas o comportamientos exigibles al empleado público cuya vulneración conlleve no solo un reproche ético sino también jurídico. Según se manifiesta en la Exposición de Motivos del EBEP estamos ante conductas directamente exigibles en la medida en que las reglas de comportamiento constitutivas del código de conducta "se incluyen en el Estatuto con una finalidad pedagógica y orientadora, pero también como límite de las actividades lícitas, cuya infracción puede tener consecuencias disciplinarias".

En este sentido, una parte de la doctrina considera que, al indicarse expresamente en el art. 52 in fine que "Los principios y reglas establecidos en este Capítulo informarán la interpretación y aplicación del régimen disciplinario de los empleados públicos", el Código de Conducta se conforma no solo en el plano del reproche ético o conductal sino incluso en el jurídico ${ }^{28}$. Es decir, pretende dotársele de cierto relieve jurídico, más allá del carácter deontológico y de la función preventiva y pedagógica que tienen este tipo de códigos ${ }^{29}$. Incluso hay quien sostiene que al margen del acierto o no de su calificación como código de conducta este se establece con vocación de constituir el principal instrumento de determinación de las conductas o comportamientos exigibles al empleado público teniendo en cuenta la integración en la prestación de sus servicios de los intereses sociales que están llamadas a satisfacer las Administraciones Públicas empleadoras"30.

En todo caso, no estamos ante simples deseos manifestados por el legislador en relación con las formas que debe revestir la actuación de los empleados públicos ya que se trata de conductas, deberes y formas de actuación previstas en una Ley y, por lo tanto, no pueden quedar desprovistas de consecuencia práctica alguna. Lo que no está tan claro, a nuestro juicio, es que la inobservancia de los deberes y pautas de actuación previstos en el EBEP conlleve la imposición de la correspondiente sanción al incumplidor.

No hay que olvidar que en la disciplina funcionarial impera el formalismo más riguroso, la estricta tipicidad de las infracciones. En este sentido entendemos con el profesor Parada Vázquez que es dudoso que estos principios (art. 52) puedan servir de criterio interpretativo para calificar concretos comportamientos funcionariales

\footnotetext{
J.A. Santamaría Pastor (Principios de Derecho Administrativo General l, 2. ${ }^{a}$ Ed., Madrid: lustel, 2009, p. 701) señala que "a la vista de estas relaciones, puede dudarse seriamente de la utilidad de la enumeración inicial de 'principios de actuación', todos los cuales se encuentran recogidos en las relaciones antedichas, y no aportando más que una notable inseguridad jurídica”.

28 Véase en este sentido Palomar Olmeda, A., Derecho de la Función Pública. Régimen Jurídico de los

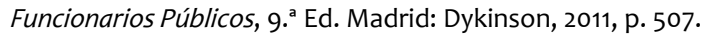

29 En este sentido se manifiesta Sánchez Morón, M., Derecho de la Función Pública, op. cit., p. 276.

30 En este sentido Gárate Castro, J "Art. 52. Deberes de los empleados públicos. Código de Conducta", op. cit., p. 505.
} 
como faltas disciplinarias y como límite de las actividades lícitas, cuya infracción pueda tener consecuencias disciplinarias ${ }^{31}$. Por el contrario, el código presenta una gran abstracción de las conductas establecidas, amplio número de conceptos indeterminados y claúsulas abiertas lo que reporta inseguridad en cuanto a su alcance y efectiva aplicación ${ }^{32}$. Así pues, el carácter informativo de estos principios respecto de las sanciones disciplinarias es probable que plantee "problemas a la hora de concretar esa 'interpretación' en un ámbito donde el rigor de la tipificación de las conductas sancionables constituye una garantía del posible sancionado"33. Por ello no parece que puedan constituir infracciones sancionables el desconocimiento de deberes jurídicos deducidos del código de conducta y de su relación con las normas de derecho discipliario a no ser que se trate de conductas legalmente tipificadas como infracciones administrativas. En este sentido, la principal crítica que suscita este "código de conducta" es su falta de sanción ya que mientras el incumplimiento de estos principios no se halle tipificado como falta disciplinaria, no pasan de ser una especie de obligación natural no exigible jurídicamente y únicamente sancionable, a lo sumo, con apercibimiento por falta leve de "incumplimiento de los deberes y obligaciones del funcionario" conforme dispone el artículo 8e) del Reglamento de Régimen Disciplinario de los Funcionarios de la Administración del Estado (en adelante RRD) ${ }^{34}$. En definitiva, no basta con el incumplimiento de un deber por un empleado público para imponerle una sanción, sino existe una tipificación previa del incumplimiento como infracción administrativa35. Por lo tanto, habrá que estar a lo que en materia de infracciones y sanciones disponga la normativa aplicable.

\subsection{El deber de objetividad de los empleados públicos en la normativa básica del empleo público}

El EBEP en el artículo 52 enumera los principios conforme a los cuales deberán actuar los empleados públicos. Se hace referencia, en primer término, al principio de

31 R. Parada Vázquez (Derecho Administrativo Il. Organización y Empleo Público, op. cit., p. 543. En el mismo sentido, entre otros, Carro Fernández-Valmayor, J.L., "Ética pública y normativa administrativa", op. cit., p. 21.

32 En este sentido se manifiesta F. A. Castillo Blanco ("Los deberes de los funcionarios públicos", op. cit., p. 398) para quien, sin embargo, ello no debe ser obstáculo para que dichas conductas sean consideradas como auténticos deberes jurídicamente exigibles. No obstante, el TC en reiteradas ocasiones ha manifestado que no es posible definir las conductas ilícitas en términos que, por su amplitud o vaguedad, dejen a las mismas en la más absoluta indefinición (STC 116/1993 y 270/1994). También es cierto, como manifiesta J.E. Quesada Lumbreras (“Título VII. Régimen Disciplinario" El Estatuto básico del Empleado Público. Comentario sistemático de la Ley 7/2007, de 12 de abril de 2007, Dir. J.L. Monereo Pérez, et al, Granada: Comares, 2008, p. 924), que a pesar de estas resoluciones del Alto Tribunal, el régimen disciplinario que venía recogiéndose en la legislación anterior y que sigue recogiéndose hoy en día, presenta un buen número de conceptos jurídicos indeterminados que, en cierta medida, vienen a flexibilizar el alcance que el principio de tipicidad presenta en el ámbito disciplinario.

33 Martín Rebollo, L. Leyes Administrativas, op. cit., p. 1597.

34 Véase en este sentido a Cámara del Portillo, D., Régimen disciplinario de los empleados públicos. La nueva regulación de la Ley 7/2007, de 12 de abril, del Estatuto Básico del Empleado Público, Madrid: Marcial Pons, 2008, p. 88 y Quesada Lumbreras, J.E., “Título VII. Régimen Disciplinario”, op. cit., p. 932.

35 STC 195/2005, de 18 de julio. 
objetividad y se reitera de nuevo al aludir, por una parte, a la imparcialidad y, por otra, a la neutralidad. Se trata de tres principos que se solapan y entre los que no existe una distinción clara. Como ya hemos puesto de manifesto más arriba, cabe entender la imparcialidad y la neutralidad como manifestaciones del más amplio deber de objetividad que debe regir la actuación de la Administración y de sus empleados públicos.

Se trata, por otra parte, de principios directamente deducibles de la Constitución (arts. 103.1 y 103.3), por lo que la Administración y los empleados públicos están obligados, por mandato constitucional, a actuar conforme a dichos principios en el ejercicio de sus funciones con el fin de servir al interés general ${ }^{36}$.

El legislador del 2007 ha optado por recoger expresamente la objetividad como una regla que debe informar el proceder del empleado público ${ }^{37}$, no obstante, de haberse omitido referencia alguna a dicho principio, las actuaciones contrarias al mismo supondrían una vulneración del art. 52 y 53.1 del EBEP. En efecto, a pesar de la rúbrica que encabeza el primero de los citados preceptos, "Deberes de los empleados públicos", es tan sólo uno, si bien no exento de relevancia por la amplitud de su contenido $^{38}$, el deber manifestado y concretado en la obligación del empleado público de "velar por los intereses generales con sujeción y observancia de la Constitución y del resto del ordenamiento jurídico". Esta obligación es reiterada de nuevo, entendemos que como consecuencia de las múltiples deficiencias técncias que padece este capítulo, en el art. 53 bajo la rúbrica "Principios éticos" en cuyo apartado primero dispone que "los empleados públicos respetarán la Constitución y el resto de normas que integran el ordenamiento jurídico”. En definitiva, las actuaciones del funcionario en servicio al interés general, en la medida en que se enmarcan en el seno de una Administración sometida a la Constitución y al resto del ordenamiento jurídico, sólo pueden tener lugar dentro del marco constitucional 39 .

Como ya hemos apuntado, la Constitución exige la actuación objetiva de la Administración en el servicio al interés general así como la imparcialidad del empleado público en el ejercico de sus funciones (art. 103.1 y 3 CE). El comportamiento del servidor público contrariando o desconociendo dichos principios constitucionales supondría, por lo tanto, una vulneración de la obligación contenida en los arts. 52 y 53.1 del EBEP. Por ello, entendemos, que la previsión expresa del deber de respeto a la Constitución

36 En este sentido A. Palomar Olmeda (Derecho de la Función Pública. Régimen Jurídico de los Funcionarios Públicos, op. cit., p. 509) señala que el servicio al interés general no es solo una determinación que corresponde a la Administración Pública en su conjunto sino que se integra en el estatuto del empleado público de forma que debe orientar el conjunto de su actividad a la realización del interés general.

37 F.A. Castillo Blanco ("Los deberes de los funcionarios públicos”, op. cit., p. 372) alude al ámbito reducido del deber de objetividad de los funcionarios públicos en la legislación anterior que tan sólo hacía referencia al deber de neutralidad e independencia políticas.

38 Este deber, como explica M. Sánchez Morón (Derecho de la Función Pública, op. cit., p. 277), se ha considerado como un correlato de la relación orgánica del funcionario con una Administración que está sometida por entero a la Constitución y al resto del ordenamiento jurídico (art. 9.1CE) y finaliza al servicio de los intereses generales que por definición, solo pueden tener lugar dentro del marco constitucional.

39 En sentido similar Sánchez Morón, M., Derecho de la Función Pública, op. cit., p. 278. 
contenido en estos preceptos sería suficiente para exigir al servidor público la observancia de un comportamiento objetivo en el desempeño de sus funciones.

Sin embargo, el legislador hace de nuevo alusión, bien explícita o implícitamente, a dicho principio en sus vertientes de neutralidad e imparcialidad, en diferentes apartados de los artículos 53 y 54:

- El art. 53 en su apartado $2 .^{\circ}$, reitera expresamente dichos principios al manifestar que la actuación de los empleados públicos "perseguirá la satisfacción de los intereses generales de los ciudadanos y se fundamentará en consideraciones objetivas orientadas hacia la imparcialidad". Aquí el legislador hace referencia a la objetividad no sólo en su vertiente de neutralidad o independencia política sino desde el punto de vista de la imparcialidad del empleado público en el ejercicio de sus funciones de manera que no pueden favorecer ilegalmente con sus actuaciones a determinadas personas. Es decir, se trata de establecer un modelo profesionalizado de empleo público y también de evitar conductas contrarias a la ética y la transparencia que debe presidir la prestación de funciones públicas que en algunos supuestos pueden comportar conductas susceptibles de calificarse como corrupción. ${ }^{40}$

- En el apartado $11 .^{\circ}$ del art. 53 se describe cómo ha de ser la actuación de los empleados públicos sin evitar hacer referencia expresa al principio del que deriva la conducta descrita: ejercerán sus atribuciones absteniéndose de conductas "que comprometan la neutralidad en el ejercicio de los servicios públicos". En la medida en que el citado apartado comienza exigiendo a los empleados públicos que ejerzan sus atribuciones según el principio de dedicación al servicio público absteniéndose de conductas contrarias al mismo, se puede afirmar que guarda una estrecha relación con el deber de diligencia del funcionario público recogido en el art. 53.10 (cumplirán con diligencia las tareas que les correspondan $)^{41}$. Ahora bien, se está aludiendo también al princpio de objetividad en el desempeño de su función al hacer referencia expresa a la citada neutralidad en la prestación del servicio, que exige al empleado público el deber de abstenerse de conocer de los asuntos en los que pueda tener interés personal o que puedan plantear un conflicto de intereses.

- Finalmente, en diferentes apartados de los citados preceptos se hace referencia a determinados comportamientos en los que se encuentran implícitos los principios de objetividad, neutralidad e imparcialidad al disponer que los empleados públicos:

40 Véase en este sentido a Castillo Blanco, F.A. y J.E. Quesada Lumbreras, “Deberes de los empleados públicos. Código de Conducta”, op. cit., p. 464.

41 En este sentido Maneiro Vázquez, Y., “Art. 53. Principios éticos”, El Estatuto básico del empleado público. Comentario sistemático de la Ley 7/2007, de 12 de abril de 2008, dir. J.L. Monereo Pérez, et al, Granada: Comares, 2008, p. 527. 
(i) “se abstendrán en aquellos asuntos en los que tengan un interés personal, así como de toda actividad privada o interés que pueda suponer un riesgo de plantear conflictos de intereses con su puesto público" (art. 53.5). Se trata de articular mecanismos que en aras a garantizar la imparcialidad del empleado público eviten la confrontación entre los intereses generales a los que aquel ha de servir, con su propio interés particular.

(ii) “no contraerán obligaciones económicas ni intervendrán en operaciones financieras, obligaciones patrimoniales o negocios jurídicos con personas o entidades cuando puedan suponer un conflicto de intereses con las obligaciones de su puesto público" (art. 53.6). El legislador trata de garantizar la imparcialidad del empleado público prohibiéndole todas aquellas actuaciones que puedan dar lugar a un conflicto de intereses de carácter económico. De todos modos, la previsión contenida en este apartado entendemos que es redundante en la medida en que esta prohibición cabría deducirla de lo previsto en términos más amplios en el apartado anterior.

(iii) “no aceptarán ningún trato de favor o situación que implique privilegio o ventaja injustificada, por parte de personas físicas o entidades privadas" (art. 53.7). Precisamente, con el fin de garantizar un comportamiento objetivo e imparcial del empleado público, este no podrá admitir ningún trato de favor que provenga de una persona física (otro empleado público, por ejemplo) o entidad privada, que le reporte algún tipo de beneficio económico o de otra índole a él o a un tercero. En todo caso, el empleado público no podrá recibir ningún tipo de remuneración por el cumplimiento de las funciones inherentes a su cargo que no proceda de los presupuestos públicos.

(iv) “no influirán en la agilización o resolución de trámite o procedimiento administrativo sin justa causa y, en ningún caso, cuando ello comporte un privilegio en beneficio de los titulares de los cargos públicos o su entorno familiar y social inmediato o cuando suponga un menoscabo de los intereses de terceros" (art. 53.9). En este apartado se realiza una concreción del deber de imparcialidad del empleado público en el ámbito de la tramitación de los procedimientos administrativos. Se produciría una vulneración evidente de dicho principio si el funcionario con su actuación a lo largo de un procedimiento trata de beneficiar a una persona por razón del cargo público que esta ocupa.

El ansia del legislador de hacer hincapié en la obligación del empleado público de comportarse en el ejercicio de sus funciones conforme a los principios constitucionales de objetividad, imparcialidad y neutralidad le lleva a desglosar el contenido de dichos principios en una serie de exigencias que contribuyen a completar, aunque de 194 un modo un tanto caótico, esta regulación. 


\section{LAS GARANTÍAS DEL DEBER DE OBJETIVIDAD DE LOS EMPLEADOS PÚBLICOS PREVISTAS EN LA LEGISLACIÓN VIGENTE}

No es posible exigir un comportamiento objetivo a los empleados públicos si previamente no queda garantizada la imparcialidad en el ejercicio de sus funciones $^{42}$. Por ello hay todo un entramado de disposiciones normativas cuyo finalidad es, entre otras, garantizar el comportamiento objetivo, imparcial y neutral de los empleados públicos en el desempeño de sus cometidos. Los pilares básicos de esta estructura garantista lo conforman: el modelo de selección y promoción del personal basado en los principios de igualdad, mérito y capacidad, el régimen disciplinario, el sistema de incompatibilidades y los mecanismos de abstención y recusación que permiten al funcionario evitar situaciones susceptibles de plantear un conflicto de intereses ${ }^{43}$.

A continuación realizaremos un breve examen de las tres últimas técnicas citadas. Dada la relevancia de la selección ${ }^{44}$ y promoción ${ }^{45}$ de los empleados al servicio de la Administración y de la entidad que alcanza el principio de objetividad en este ámbito, se le dedica un estudio independiente en esta obra al que nos remitimos.

42 En este sentido Marina Jalvo, B., El régimen disciplinario de los funcionarios públicos, 2. ${ }^{a}$ Ed., Valladolid: Lex Nova, 2001, p. 47.

43 Véase en este sentido Marina Jalvo, B., El régimen disciplinario de los funcionarios públicos, op. cit., p. 47.

44 Como es sabido, el acceso al empleo público es una pieza clave de todo el sistema. En este sentido E. Malaret i García ("El Estatuto básico del empleado público, la modernización administrativa en el Estado de las Autonomías: un proceso en construcción”, RVAP, n. $84,2009, \mathrm{p} .192$ ), resalta que las reglas que disciplinan el inicio de la relación de servicio constituyen seguramente una de las especificidades más relevantes de la función pública, a diferencia de la libertad de contratación que rige en la esfera privada. De ahí que el personal funcionario y laboral deba ser seleccionado mediante procedimientos en los que se garantice el respeto a los principios constitucionales de igualdad, mérito y capacidad lo que exige, inexorablemente, una actuación imparcial y objetiva de los miembros de los órganos de selección a lo largo del proceso selectivo. Al respecto puede consultarse, entre otros, mi trabajo "EBEP: ¿Modernización o continuidad en la regulación de los procesos de selección de los empleados públicos”, Dereito. Estudios sobre la modernización administrativa, monográfico, 2011, pp. 201-230.

45 Como sostiene A. Palomar Olmeda (Derecho de la función pública. Régimen jurídico de los funcionarios públicos, op. cit., p. 328), los citados principios de igualdad, mérito y capacidad no quedan únicamente vinculados al acceso a la función pública sino que, por exigencia de los principios organizadores de la Administración Pública -objetividad, imparcialidad y eficacia- a los que se refiere el art. 103.1 CE, se extiende su aplicación a la promoción profesional en su conjunto.

Los artículos 16.1 y 19.1 sancionan, respectivamente, el derecho de los funcionarios de carrera y del personal laboral a la promoción profesional. Este Derecho se hace efectivo a través de la la carrera profesional y la promoción interna según los principios constitucionales de igualdad, mérito y capacidad mediante la implantación de sistemas objetivos y transparentes de evaluación. En este ámbito el EBEP ha introducido dos importantes novedades, la carrera horizontal de los funcionarios públicos por un lado y, en estrecha conexión con la misma, la denominada evaluación de desempeño. Un estudio minucioso y exhaustivo sobre esta cuestión puede verse en Almeida Cerreda, M., "La evaluación del desempeño de los empleados públicos. En particular, el establecimiento de sistemas de evaluación del desempeño en las Administraciones locales", Anuario de Derecho Municipal, n. ${ }^{3}$, 2009, pp. 115-158. 


\subsection{La protección de la imparcialidad de la Administración a través de los mecanismos de abstención y recusación}

La Ley 30/1992, de 26 de noviembre, de Régimen Jurídico de las Administraciones Públicas y del Procedimiento Administrativo Común (en adelante LPC) dispone, en garantía del deber de objetividad de la Administración y del de imparcialiad de las autoridades y personal a su servicio, que quienes tienen la competencia para tramitar y resolver un procedimiento deberán abstenerse de intervenir en el mismo si concurren las causas previstas en el art. 28 de la $\mathrm{LPC}^{46}$. En este precepto el legislador detalla una serie de motivos que podrían debilitar la imparcialidad que debe revestir toda actuación de los empleados públicos y que son, asimismo, las causas que fundamentan su recusación por parte de los interesados en la tramitación del procedimiento ${ }^{47}$. Se trata, en definitiva, "de evitar que determinadas personas influyan en la elaboración de una decisión administrativa y ello, en primer lugar, para asegurar que esa decisión es la más justa y adecuada a los intereses públicos implicados y, en segundo lugar, para legitimarla despejando las sospechas que pudiesen existir sobre la objetividad de la Administración" ${ }^{48}$.

Pueden estar incursas en alguna de las causas de abstención previstas en la legislación vigente y, por lo tanto, no pueden intervenir en la tramitación del procedimiento del que se ha de derivar una decisión justa y objetiva, tanto el titular del órgano competente para emitir la resolución definitiva como el resto de empleados públicos que han de adoptar decisiónes de algún tipo a lo largo de la tramitación del mismo ${ }^{49}$. En definitiva, el deber de abstención se predica de todos aquellos servidores públicos que intervienen en la tramitación y resolución del procedimiento y que con su intervención pueden influir sobre el contenido del acto que ponga fin al procedimiento ${ }^{50}$.

46 G. Doménech Pascual ("La abstención en el procedimiento administrativo”, Nuevas perspectivas del Régimen Local. Estudios en Homenaje al Profesor José M. ${ }^{a}$ Boquera Oliver, coord. J.M. Baño León y J. Climent Barberá, Valencia: tirant lo blanch, 2002. p. 412) sostiene que la abstención garantiza la igualdad de los interesados en el procedimiento, les proporciona confianza en la objetividad de la actuación administrativa, legitima dicha actuación y evita situaciones incómodas, "conflictos de conciencia”, los sujetos obligados a abstenerse.

47 El TC en su Sentencia 235/2000 de 5 de octubre apunta que "la imparcialidad en el ejercicio de la función pública viene garantizada [...] por una serie de caulelas legales, entre las que ocupa un lugar destacado la obligación de abstención y la posibilidad de recusación de los funcionarios cuando concurren determinadas circunstancias previstas legalmente que pueden poner en peligro objetivo la rectitud de su actuación" (FJ 13).

48 Doménech Pascual, G., "La abstención en el procedimiento administrativo", op. cit., p. 459.

49 No obstante, como pone de manifiesto G. Domenech Pascual (La abstención en el procedimiento administrativo", op. cit., p. 441), el servidor público incurso en causa de abstención no tiene absolutamente vedada toda intervención en el procedimiento administrativo. Así, por ejemplo, si es interesado en el mismo, puede efectuar alegaciones, proponer pruebas, tiene derecho a ser oído, etc.; en suma, puede actuar en el procedimiento defendiendo sus intereses particulares. Lo que se le prohibe es participar en él desempeñando las funciones propias del puesto de trabajo que ocupa en el seno de la organización administrativa, funciones que deben ser realizada siempre con el fin de satisfacer el interés general". Asimismo, el TS en su Sentencia de 10 de octubre de 1997 (RJ 7642), declara que no constituye ilegalidad alguna el hecho de que una persona presuntamente incursa en causa de abstención se limite a practicar una notificación.

50 González Pérez, J., y F. González Navarro. Comentarios a la Ley de Régimen Jurídico de las Administraciones Públicas y del Procedimiento Administrativo Común, Madrid: Civitas, 1999, p. 834. 
De acuerdo con el citado artículo 28 de la LPC las causas que determinan la imposibilidad de intervenir en un procedimiento se pueden clasificar en tres tipos ${ }^{51}$ :

(i) la existencia de relaciones de índole personal entre el empleado público y los interesados:

- el parentesco de consanguinidad dentro del cuarto grado o de afinidad dentro del segundo, con cualquiera de los interesados, con los administradores de entidades o sociedades interesadas, o con los asesores, representantes legales o mandatarios que intervengan en el procedimiento (art. 28.2.b). Como pone de manifiesto Domenech Pascual, este es un motivo de abstención que no plantea problemas concretos sobre todo debido a la facilidad con la que puede demostrarse su existencia52.

- la amistad íntima o enemistad manifiesta con alguno de los citados (28.2.c). En relación con este supuesto, la jurisprudencia en atención a la dificultad que presenta su prueba, ha entendido que ha de acreditarse "al menos, por medio de prueba indiciaria" 53 .

- tener cuestión litigiosa pendiente con algún interesado. La doctrina entiende que el legislador, en este supuesto, se ha querido referir no sólo a aquellos casos en los que el empleado público litiga contra algún interesado sino también en los supuestos en que ambos forman litisconsorcio ${ }^{54}$. Por otra parte, es necesario que el litigio se encuentre pendiente, es decir, que se haya iniciado antes que el procedimiento administrativo. Asimismo, la cuestión litigiosa debe entenderse pendiente directamente entre el interesado y el servidor público quedando excluidos aquellos supuestos en los que este actua en el pleito defendiendo los intereses de la parte de la parte contraria al interesado 55 .

(ii) la existencia de relaciones de índole profesional:

- compartir despacho profesional o estar asociado con éstos para el asesoramiento, la representación o el mandato (art. 28.2b)

51 Esta ordenada clasificación de las causas de abstención recogidas en la LPC ha sido realizada por J.M. Santamaría Pastor, Principios de Derecho Administrativo General II, Madrid:iustel, 2006, pp. 39-40.

52 Domenech Pascual, G., “La abstención en el procedimiento administrativo”, op. cit., p. 431.

53 TSTJ de Asturias de 7 de noviembre de 1997, RJ. 2835.

54 Domenech Pascual, G., “La abstención en el procedimiento administrativo”, op. cit., p. 431.

55 En este sentido el TS en su Sentencia de 23 de febrero de 1998 (RJ 2364) señala que "la cuestión litigiosa que invoca el actor en apoyo de la recusación de [... ] es la planteada entre él y su ex cónyuge, sin que la existencia del procedimiento de divorcio, ni la del incidente de ejecución de la sentencia recaída en el mismo, autoricen a entender que existe también una cuestión litigiosa entre los profesionales que han asumido la representación y defensa de cada parte y la contraria, como pretende el recurrente, ya que es obvio que dichos profesionales, en cuanto tales, no actúan en el proceso ejercitando derechos o intereses propios". 
- tener relación de servicio con persona natural o jurídica interesada directamente en el asunto, o haberle prestado en los dos últimos años servicios profesionales de cualquier tipo y en cualquier circunstancia o lugar (art. 28.2.e).

(iii) la existencia de una conexión de intereses con el objeto del procedimiento:

- tener el empleado público relación personal en el asunto de que se trate o en otro cuya resolución pudiera influir la de aquél o ser administrador de alguna de las sociedades o entidades interesadas en el procedimiento (art. 28.2.a). Para que se de este motivo no es necesario que el empleado público o sociedad correspondiente tengan la condición de interesado en el procedimiento sino que es suficiente que sean titulares de derechos o intereses legítimos que puedan resultar perjudiciados o beneficiados por la decisión que se adopte $^{56}$. Ahora bien, la jurisprudencia señala que esa prohibición de intervención, con la consiguiente obligación de abstención, debe tener lugar cuando se refiere a asuntos estrictamente privados y no cuando afecta a los públicos e institucionales en los que de alguna manera se ve afectada la esferea privada 57 .

- haber intervenido como perito o como testigo en el procedimiento de que se trate (art. 28.2.d).

En definitiva, la legislación vigente sí ofrece mecanismos para garantizar la imparcialidad del empleado público en el seno de la tramitación de un procedimiento. Estamos ante un deber y principio ético sancionado en el código de conducta del EBEP tal y como cabe inferir, en primer término, de la obligación general de imparcialidad que debe regir cualquier actuación de los empleados públicos según reza el apartado 2 del artículo 53. Posteriormente, este deber se reitera de una forma más concreta al ordenar, en el apartado quinto del citado precepto, la abstención de los servidores públicos en aquellos asuntos en los que tengan un interés personal.

Para concluir este apartado cabe señalar que la intervención en el procedimiento administrativo con capacidad decisoria cuando se de algunas de las causas de abstención legalmente señalas se encuentra tipificado como falta grave en el Reglamen-

56 En este sentido Domenech Pascual, G., “La abstención en el procedimiento administrativo”, op. cit., p. 429. El autor cita la Sentencia del TS de 28 de junio de 1982 (RJ 3581) que define dicho interés como la "relación que une a la autoridad decisoria con el objeto del expediente, de forma que la primera pueda experimentar algún tipo de beneficio o perjuicio como consecuencia de la resolución del procedimiento".

57 Véase en este sentido la STSJ de Extremadura de 12 de mayo de 1998 (RJ 2203) que sigue la doctrina del TS, entre otras, en su Sentencia de 25 de junio de 1991 (RJ 6326). En esta resolución el Alto Tribunal señala que "las circunstancias que la Sala tiene en cuenta para no servirse del interés personal del referido Alcalde en el otorgamiento de la licencia de que se trata convirtiéndolo en motivo de nulidad del acto, principalmente son las siguientes: 1 . $^{\mathrm{a}}$ ) La de que dicho interés no ha sido incompatible con la defensa 198 perjudicarle....". 
to de Régimen Disciplinario de los Funcionarios de la Administración del Estado. Sobre esta cuestión volvermos más adelante.

\subsection{Régimen de incompatibilidades en garantía de la imparcialiad}

Otra garantía objetiva de la imparcialidad es el régimen de incompatibilidades. Su finalidad primordial es evitar el conflicto de intereses entre las actividades públicas y privadas de los empleados públicos, sean funcionarios o contratados en régimen laboral ${ }^{58}$. Su regulación se encuentra prevista con carácter básico en la Ley 53/1984, de 26 de diciembre, de Incompatibilidades del Personal al Servicio de las Administraciones Públicas (en adelante LI) ${ }^{59}$.

Conforme a la misma, son incompatibles con el desempeño de un puesto de trabajo en el sector público el ejercicio de cargos, profesiones o actividades públicas o privadas, que puedan impedir o menoscabar el estricto cumplimiento de los deberes del empleado público o comprometer su imparcialidad o independencia ${ }^{60}$. Así pues, la incompatibilidad se puede producir entre (i) dos o más actividades públicas, (ii) con una actividad privada que pueda implicar un conflicto de intereses o perjudicar la imparcialidad del empleado público y (iii) con cualesquiera otras actividades privadas en las que no exista riesgo de confrontación de intereses.

De esta clasificación lo que ahora nos interesesa es la categoría citada en segundo lugar, esto es, las incompatibilidades en garantía de la imparcialidad que, conforme a lo dispuesto en el artículo 11.1 de la LI, implica la imposibilidad, para quien desrempeñe un puesto de trabajo en el sector público, “de ejercer, por sí o mediante sustitución, actividades privadas, incluidas las de carácter profesional, sean por cuenta propia o bajo la dependencia o al servicio de Entidades o particulares que se relacionen directamente con las que desarrolle el Departamento, Organismo o Entidad donde estuviera destinado". El legislador se ha preocupada de establecer una serie de precisiones a esta regulación general en el artículo siguiente en donde dispone que, en todo caso, el empleado público no podrá ejercer:

- El desempeño de actividades privadas, incluidas las de carácter profesional, sean por cuenta propia o bajo la dependencia o al servicio de Entidades o particulares, en los asuntos en que esté interviniendo, haya intervenido en los dos últimos años o tenga que intervenir por razón del puesto público. Se

58 Art. 2.2. de la Ley 53/1984, de 26 de diciembre.

59 Como es sabido, es esta la única parte de la legislación general básica en materia de empleo público que no se incluye en el EBEP a pesar de las recomendaciones de la Comisión para el estudio y preparación del Estatuto Básico del Empleado Público. Según el informe elaborado por esta Comisión el EBEP debería recoger la regulación de esta materia, incluso con cierto grado de detalle, para garantizar la igualdad de los empleados en este aspecto clave de la relación de servicio. Véase el Informe de la Comisión para el estudio y preparación del Estatuto Básico del Empleado Público, p. 207).

60 Art. 1.3 de la Ley 53/1984 de 26 de diciembre. 
incluyen en especial en esta incompatibilidad las actividades profesionales prestadas a personas a quienes se esté obligado a atender en el desempeño del puesto público.

- La pertenencia a Consejos de Administración u órganos rectores de Empresas o Entidades privadas, siempre que la actividad de las mismas esté directamente relacionada con las que gestione el Departamento, Organismo o Entidad en que preste sus servicios el personal afectado.

- El desempeño, por sí o por pesona interpuesta, de cargos de todo orden en Empresas o Sociedades concesionarias, contratistas de obras, sevicios o suministros, arrendatarias o administradoras de monopolios, o con participación o aval del sector público, cualquiera que sea la configuración jurídica de aquellas.

Al margen de estas excepciones, el empleado público deberá obtener el reconocimiento de compatibilidad para el ejercicio de una actividad privada.

Con todas estas reglas el legislador trata de proteger y garantizar la imparcialidad como bien jurídico inherente a la condición de empleado público. Ahora bien, este régimen de incompatibilidad establecido en garantía de la actuación imparcial del empleado público, debería completarse con unas previsiones más estrictas en atención al puesto de trabajo que ocupan y las funciones que realizan determinados servidores públicos. En este sentido se manifiesta también la Comisión para el estudio y preparación del Estatuto Básico del Empleado Público cuando propone que las reglas generales de incompatibilidades deberían "ser completadas con algunas otras específicas, más estrictas, referidas a aquellos empleados, fundamentalmente de nivel superior, que ejerzan funciones relativas a la adjudicación de contratos, autorizaciones, licencias, subvenciones y otros derechos, así como para los empleados de las autoridades u organismos de regulación y control de los mercados, y para quienes desempeñan funciones de inspección y sanción sobre particulares y empresas privadas" 61 . No obstante, como es sabido, para sancionar la incompatibilidad no es necesario demostrar que el afectado ha actuado con parcialidad. Asimismo, aquel no puede alegar en su descargo la falta de intención de causar perjuicio alguno al interés público con su actuación ${ }^{62}$.

Volviendo al tema central que nos ocupa, cabe observar como en estrecha relación con el sistema de incompatibilidades previsto, se encuentran las obligaciones establecidas en los artículos 53.5 y 53.6 del EBEP que determinan, respectivamente, tanto el deber del empleado público de abstenerse de toda actividad privada o interés que pueda suponer un riesgo de plantear conflicto de intereses con su puesto

61 Informe de la Comisión para el estudio y preparación del Estatuto Básico del Empleado Público, p. 211.

62 Sánchez Morón, M., Derecho de la función pública, op. cit., p. 279. 
público, como la imposibilidad de contraer obligaciones económicas, intervenir en operaciones financieras, obligaciones patrimoniales o negocios jurídicos con personas o entidades cuando pueda suponer un conflicto de intereses con las obligaciones de su puesto público.

Estamos ante principios éticos que han de regir la actuación de los empleados públicos que, además de encontrarse tutelados por la legislación de incompatibilidades, también lo están, como luego veremos, por el régimen disciplinario administrativo y, en aquellos supuestos de especial gravedad, por el propio derecho penal, cuando las conductas de los empleados públicos encajen en alguno de los tipos penales previstos (cohecho, tráfico de influencia, malversación de fondos públicos, etc.).

\subsection{El régimen disciplinario: la tipificación y correspondiente sanción de las actuaciones contrarias al principio de objetividad}

Dentro del abanico de medidas previstas para garantizar la imparcialidad del funcionario en el ejercicio de sus funciones cabe hacer referencia, en tercer lugar, al régimen disciplinario ${ }^{63}$. Como es sabido, la responsabilidad disciplinaria de los funcionarios es aquella que se desarrolla en el interior de la relación de servicio y en garantía del cumplimiento de los deberes y obligaciones del funcionario, con sanciones que inciden sobre sus derechos ${ }^{64}$. En este sentido, el ordenamiento jurídico dispone las medidas sancionadoras pertinentes para el supuesto de que el empleado público, infringiendo el deber de imparcialidad, cometa con su actuación alguna de las infracciones tipificadas en las normas disciplinarias. $Y$, todo ello, al margen de la responsabilidad penal en que pueda incurrir como consecuencia de una infracción considerada por su gravedad como delito tipificado y sancionado como tal en el Código Penal.

Analizaremos a continuación en qué medida la inobservancia de los comportamientos, conductas y formas de proceder de los empleados públicos recogidos en el Código de Conducta puede ser objeto de una sanción disciplinaria por encontrarse dicha actuación tipificada como una infracción en el EBEP. Ya hemos señalado unas páginas atrás que no basta, conforme a la jurisprudencia constitucional, con el incumplimiento de un deber por un empleado público para imponerle una sanción si previamente no existe una tipificación del incumplimiento como infracción administrativa. Como hemos apuntado, es cierto que el Código de Conducta se limita a informar la interpretación y aplicación del régimen disciplinario incluyendo sus reglas en el Estatuto con finalidad pedagógica y orientadora y también como límite de las actividades

63 En este sentido el Informe de la Comisión para el estudio y preparación del Estatuto Básico del Empleado Público (op. cit., p. 214) señala que "aunque la difusión de los valores éticos del servicio, sea a través de su asunción cultural por el conjunto de los empleados públicos, sea a través de actividades específicas de formación, sea a través de códigos de conducta, constituya una garantía cada vez más importante del cumplimiento de los deberes de los empleados públicos, es obvio que la regulación de un régimen disciplinario efectivo resulta imprescindible para asgurar la responsabilidad de aquellos".

64 Parada Vázquez, R., Derecho Administrativo Il. Organización y empleo público, op. cit., p. 564. 
lícitas, cuya infracción puede tener consecuencias disciplinarias (Exposición de Motivos del EBEP). Pero, en ningún caso, el Código de conducta realiza una tipificación de las faltas disciplinarias. De forma que será necesario analizar en qué medida existe una correlación entre las faltas disciplinarias y las distintas manifestaciones del deber de imparcialidad de los funcionarios públicos en el ejercicio de sus funciones recogidos en el artículo 53 del citado Código.

Conforme al artículo 93 los funcionarios públicos y el personal laboral quedan sujetos al régimen disciplinario establecido en el presente Título y en las normas que las Leyes de Función Pública dicten en desarrollo de este Estatuto (apartado $1 .^{\circ}{ }^{65}$. Como ya es conocido, las faltas se clasifican en muy graves, graves y leves. Sólo la tipificación de las infracciones muy graves y las correspondientes sanciones están recogidas en el EBEP, artículos 95.2 y 96 respectivamente ${ }^{66}$. Estos preceptos, como hemos dicho, son de aplicación tanto a funcionarios como al personal laboral ${ }^{67}$. Sin

65 J.E. Quesada Lumbreras ("Título VII. Régimen disciplinario”, op. cit., pp. 913-914) en relación con este artículo hace alusión a que en él se encuentra una de las múltiples deficiencias técnicas de este capítulo VII ya que si bien se dice en este precepto que los funcionarios y el personal laboral quedan sujetos al presente régimen disciplinario posteriormente añade y a "las leyes de Función Pública que se dicten en desarrollo del Estatuto" sin hacer mención alguna a la legislación laboral aplicable en la materia. No obstante, a juicio del autor, lo importante es que con este precepto, se determina que la reglamentación o legislación que se dicte en desarrollo de este Estatuto, debe realizarse en base a unos mínimos principios de régimen disciplinairo comunes tanto para los funcionarios públicos como para el personal laboral al servicio de las Administraciones Públicas.

66 Se lleva a cabo esta tipificación a pesar de que en el Informe de la Comisión para el estudio y preparación del Estatuto Básico del Empleado Público (op. cit., p. 217) se puso de manifiesto que no era necesario que fuese el propio EBEP la norma que contenga el listado de las infracciones sancionables. Ya que una regulación semejante supondría descender a un grado de detalle poco compatible con la idea de Estatuto "de mínimos" que venimos sosteniendo. Tampoco tendría demasiada explicación, asegura el informe, que se tipificaran en el Estatuto sólo algunas infracciones, las muy graves, y otras no, pues entendemos que deben ser las leyes del Estado y de las Comunidades Autónomas las que determinen en cada caso qué gravedad se atribuye a cada tipo sancionador.

67 Esta proclamada unificación de regímenes en materia disciplinaria dista mucho de haberse conseguido ya que, como ha puesto de manifiesto D. Cámara del Portillo (Régimen disciplinario de los funcionarios públicos. La nueva regulación de la Ley 7/2007, de 12 de abril, del Estatuto Básico del Empleado Público, op. cit., p. 10), la legislación autonómica puede añadir a ese catálogo establecido con carácter básico otras faltas muy graves y otras sanciones (arts. 95.2. letra p) y 96.1 letra g). En efecto, en el art. 95.2 se señala que tendrán la consideración de faltas muy graves las que queden así tipificadas en Ley de las Cortes Generales o de la Asamblea Legislativa de la correspondiente Comunidad Autónoma o por los convenios colectivos en el caso del personal laboral. Así también lo anunciaba la Exposición de Motivos del EBEP cuando señala que "en cuanto al régimen disciplinario, el Estatuto, de conformidad con su carácter básico, se limita a ordenar los principios a que debe someterse el ejercicio de esta postestad pública [...] tipifica las infracciones muy graves y amplia el abanico de posibles sanciones. Por lo demás, se remite ampliamente a la legislación que, en su desarrollo dicten el Estado y las Comunidades Autónomas en el ámbito de sus respectivas competencias".

Como pone de manifiesto A.V. Sempere Navarro y F.J. Hierro Hierro ("Título VII. Régimen disciplinario", Comentarios a la Ley 7/2007, de 12 de abril, del Estatuto Básico del Empleado Público, dir. A. Palomar OImeda y A.V. Sempere Navarro, Aranzadi, 2008, p. 810) el EBEP establece reglas de interrelación entre él mismo y distintos ordenamientos normativos -legislación de las Cortes Generales, de las Comunidades Autónomas y convenios colectivos-, lo que en estos supuestos puede dar lugar no sólo a situaciones de discriminación o agravio comparativo entre los distintos empleados públicos de diversas Administraciones sino también entre empleados de la misma Administración al encontrarse sujetos a ordenamientos jurídi- 
embargo, por lo que se refiere a las faltas graves, para este último colectivo serán de aplicación las previsiones recogidas al respecto en los convenios colectivos en virtud de la remisión realizada a los mismos por el artículo 95.3 del EBEP. En lo que respecta a los funcionarios, la tipificación de las faltas graves se regulará en una Ley de las Cortes Generales o de la Asamblea legislativa de la correspondiente Comunidad Autónoma (art. 95.3). Por lo que se refiere a las faltas leves el régimen aplicable, tanto a funcionarios como a contratados en régimen laboral, será el que determinen las leyes de función pública que se dicten en desarrollo del EBEP (art. 95.4) ${ }^{68}$. En la actualidad, y a la espera de que se dicten las citadas normas legales, en el ámbito estatal las faltas graves y leves que en inobservacia de sus obligaciones pueden cometer los funcionarios se encuentran tipificadas en el aun vigente Reglamento de Régimen Disciplinario de los Funcionarios de la Administración del Estado, aprobado por Real Decreto $33 / 1986$ de 10 de enero (en adelante RRD) ${ }^{69}$. Asimismo, este reglamento, a pesar de su más que cuestionable respeto al principio de legalidad sancionadora, es aplicable a los funcionarios de aquellas Comunidades Autónomas que no han regulado estas infracciones en sus propias leyes de función pública ${ }^{70}$. En este análisis nos ocuparemos de las faltas que impliquen una vulneración del deber de objetividad de los empleados públicos que se encuentren tipificadas en la normativa estatal.

En primer lugar, el art. 95.2 del EBEP señala en su apartado a) como falta muy grave "el incumplimiento del deber de respeto a la Constitución y a los respectivos

cos dispares, aun si bien la tendencia de los últimos años ha sido hacia la homogeneización del régimen disciplinario. Para el citado autor, "lo que a buen seguro provocará esta remisión o delegación normativa será complejidad y disfuncionalidad ante la necesidad de simultanear varios bloques normativos para el intérprete y aplicador del Derecho".

68 Sempere Navarro, A.V. y F.J. Hierro Hierro (“Título VII. Régimen disciplinario", op. cit., p. 811) entienden que esta regulación presenta un panorama nada halagüeño para el aplicador de la norma y más si cabe en lo atinete al personal laboral, ya que en todo caso se verá obligado a la utilización de tres sistemas normativos.

69 La Secretaría General para la Administración Pública en sus Instrucciones de 5 de junio de 2007 para la aplicación del EBEP (BOE de 23 de junio) ha entendido que, en el ámbito de la Administración General del Estado y sus organismos públicos "sigue vigente el Reglamento de Régimen Disciplinario de los Funcionarios de la Administración General del Estado, aprobado por Real Decreto 33/1986, de 10 de enero, así como los convenios colectivos de personal laboral en todo lo que no resulten incompatibles con los dispuesto en este Título". De acuerdo con E. Arribas López (Sobre la vigencia del régimen disciplinario de los funcionarios después del Estatuto Básico del Empleado Público: “Interpretación mecanicista” versus “interpretación teleológica”, Revista General de Derecho Administrativo, n. ²6, 2011) del régimen transitorio establecido en el EBEP cabe deducir que la normativa legal y reglamentaria que hace referencia al régimen disciplinario de los funcionarios públicos continúa vigente en tanto no sea sustituido por las nuevas normas dictadas en desarrollo del propio EBEP. El autor en este trabajo pone de manifiesto y fundamanta, a nuestro juicio de forma acertada, su discrepancia con la doctrina sobre régimen disciplinario de los funcionarios públicos contenida en la Sentencia del Tribunal Superior de Justicia de Valencia, de 28 de julio de 2010, que sostiene que sólo está vigente la tipificación que realiza la Ley 772007, de 12 de abril, del Estatuto Básico del Empleado Público, de las faltas disciplinarias muy graves, mientras que debe considerarse derogada la tipificación de las faltas graves y leves que realiza el Reglamento de Régimen Disciplinario de los Funcionarios de laAdministración del Estado, aprobado por Real Decreto 33/1986, de 10 de enero.

70 De manera que el reglamento estatal que carece de carácter básico, sí se aplicaría de forma supletoria en el ámbito autonónico con el fin de evitar que conductas dañosas para el interés público queden impunes. 
Estatutos de Autonomía de las Comunidades Autónomas y Ciudades de Ceuta y MeliIla, en el ejercicio de la función pública".

Esta falta ya se encontraba tipificada en el artículo 31 de la Ley 30/1984, de 2 de agosto, de Medidas para la Reforma de la Función Pública en la que se hacía referencia al deber de "fidelidad" a la Constitución en el ejercicio de la función pública. Según la opinión doctrinal mayoritaria dicho deber se encuentra implícito en el artículo 103.1 de la Constitución ${ }^{71}$. De modo que, si bien, la fidelidad de los funcionarios a la Constitución no fue formulada expresamente por dicha Norma, puede considerarse implícita en el mandato de imparcialidad de los funcionarios y en la postura servicial y objetiva de la Administración Pública72.

Cabe resaltar que siguiendo las recomendaciones del Informe realizado por la Comisión para el estudio y preparación del EBEP el concepto de fidelidad se ha sustituido por el de "respeto" a la Constitución, en la medida en que este último expresa una "menor carga de compromiso político y mayor respeto de la libertad ideológica de los empleados públicos, a los que no se exige la adhesión personal al sistema de valores, principios y normas constitucionales y estatutarias. Pero sí no realizar acciones contra dicho sistema mientras estén ejercitando sus funciones públicas"73.

En la actualidad este deber se encuentra recogido de forma expresa en los artículos 52 y 53.1 del EBEP al disponer que los empleados públicos tienen la obligación de servir al interés general con sujección y observancia de la Constitución. Asimismo, cabe conectar este deber con la exigencia de objetividad manfiestada en el art. 53.2 del Estatuto en el que, como se recordará, se compele a los empleados públicos a perseguir "la satisfacción de los intereses generales de los ciudadanos" fundamentando su actuación "en consideraciones objetivas orientadas hacia la imparcialidad y el interés común, al margen de cualquier otro factor que exprese posiciones personales, familiares, corporativas, clientelares o cualesqueira otras que puedan colisionar con este principio".

Si bien este deber de objetividad de los empleados públicos se garantiza en el procedimiento de selección del funcionariado conforme a los principios de mérito y capacidad "debe extenderse a la vigencia de la relación funcionarial y traducirse en un deber de respeto, común y por igual de todos los funcionarios públicos, a los fundamentos básicos de la Constitución española entendiendo por tales los valores superiores del ordenamiento jurídico, el principio de soberanía nacional, la forma política de Estado y los órganos constitucionales y otros específicos deberes exigibles solamente a concretos Cuerpos de Funcionarios públicos"74.

71 Veánse entre otros a Embid Irujo, A., La fidelidad de los funcionarios a la Constitución (Un estudio de los derechos alemán y español), Madrid: INAP, 1987, p. 164 y Lafuente Benaches, M., El régimen disciplinario de los funcionarios públicos de la Administración del Estado, Valencia: tirant lo blanch, 1996, p. 43.

72 Marina Jalvo, B., El régimen disciplinario de los funcionarios públicos, op. cit., p. 322.

73 Sánchez Morón, M., "Régimen disciplinario", Comentarios a la Ley del Estatuto Básico del Empleado Público, 2. ${ }^{a}$ Ed., Valladolid: Lex Nova, 2008, p. 547.

74 Lafuente Benaches, M., El régimen disciplinario de los funcionarios públicos de la Administración 204 del Estado, op. cit., p. 44. 
Cabe por lo tanto concluir que, de conformidad con la legislación y jurisprudencia analizada, se encuentra tipificada como falta muy grave en el citado art. 95.2 apartado a) del EBEP la vulneración de los principios sobre los que se asienta la Norma Constitucional, entre otros, el principio de objetividad de la Administración que halla su fundamento, como hemos señalado, en el art. 103.1 CE. Deber que en la actualidad también hay que entender implícito en los arts. 52 y 53.1 del EBEP. Ahora bien, la propia jurisprudencia ha resaltado que "no puede incluirse en el mismo cualquier tipo de incumplimiento de un deber funcionarial, sino una eficaz y positiva infidelidad a la Constitución entendida en su conjunto, como norma básica reguladora de la convivencia ciudadana"75. Todo ello al margen, por supuesto, de las conductas especialmente graves sancionadas por el Código Penal.

Por otra parte, la infracción del deber constitucional de objetividad en su estricta vertiente de neutralidad política se garantiza tipificando como falta muy grave "la discriminación por razón de opinión” (art. 95.2.b) y sancionando "la violación de la imparcialidad, utilizando las facultades atribuidas para influir en procesos electorales de cualquier naturaleza y ámbito" (art. 95.2.h). Con esta última previsión se sanciona el deber de neutralidad política del empleado público mediante cualquier forma de influencia interesada del funcionario en el desarrollo de todo tipo de procesos electorales o en la intención de los electores ${ }^{76}$.

El incumplimiento de las normas sobre incompatibilidades cuando ello dé lugar a una situación de incompatibilidad también está tipificada como infracción muy grave en el EBEP, art. 95.2 letra n). Como ya hemos visto las normas sobre incompatibilidades tratan de garantizar la imparcialidad del funcionario evitando conflictos que puedan surgir como consecuencia de la realización de actividades privadas junto al desempeño de su función pública. Lo que se tipifica en este precepto son las conductas que impliquen el ejercicio real de las actividades que son incompatibles. En este sentido el TS manifiesta que esta falta tipificada como muy grave responde a la "finalidad de eliminar situaciones reales de pérdida de la debida independencia o neutralidad en la función, así como evitar el peligro de que ello pueda producirse, reforzando la credibilidad en las personas que desempeñan funciones públicas"77.

Se sanciona, por lo tanto, la vulneración por parte del empleado público del régimen de incompatibilidades regulado por la Ley 53/1984 de 26 de diciembre de incompatibilidades del personal al servicio de las Administraciones públicas. Encajan en ese tipo los deberes recogidos en los artículos 53.5 (se abstendrán de toda actividad privada o interés que pueda suponer el riesgo de plantear conflicto de intereses con su puesto público) y 6 (no contraerán obligaciones económicas ni intervendrán en operaciones financieras, obligaciones patrimoniales o negocios jurídicos con personas o

75 STS de 28 de noviembre de 1991 (RJ 8831).

76 Marina Jalvo, B., El régimen disciplinario de los funcionarios públicos, op. cit., p. 332.

77 STS de 15 de octubre de 1994 (RJ 8034). Se refiere el Tribunal a la falta muy grave del art. 31.1.h) que es hoy la prevista en el 95.2. n) 
entidades cuando pueda suponer un conflicto de intereses con las obligaciones de su puesto público) del EBEP. En definitiva, ambos preceptos disponen la obligación de abstención del funcionario en la realización de actuaciones que puedan plantear un conflicto de intereses con el sector público. Esta obligación de abstención debe cumplirse mientras no se dicte por la autoridad competente una autorización o reconocimiento de compatibilidad ${ }^{78}$.

Sin embargo, está sancionada como falta grave el incumplimiento de los plazos u otras disposiciones en materia de incompatibilidades, cuando no suponga mantenimiento de una situación de incompatibilidad (art. 7.1.k RRD). Pues bien, a diferencia de la infracción tipificada en el art. 95.2. n), ahora se sanciona la inobservancia de prazos o procedimientos establecidos con el fin de obtener la compatibilidad para el desempeño de dos puestos de trabajo. Es decir, se sanciona a quien encontrándose en una situación jurídicamente permitida, lo está al margen de las previsiones legales. Lo fundamental del tipo descrito y que lo diferencia del anterior es que la transgresión del funcionario, al sancionarse, no es reconducible a la declaración de incompatibilidad79 por lo que en consecuencia no vulnera, en ningún caso, el deber de imparcialidad.

Finalmente, la intervención en un procedimiento administrativo cuando se de alguna de las causas de abstención legalmente señaladas ${ }^{80}$ está tipificado, como ya hemos señalado, como falta grave en el artículo 7 letra g) del RRD. Con ello se sanciona la actuación contraria al deber de imparcialidad de los empleados públicos que intervienen en asuntos en los que tienen obligación de abstenerse por concurrir alguna de las causas legalmente previstas. Es indiferente, para que concurra el tipo previsto, que el empleado público incurso en la causa de abstención haya actuado beneficiando al interesado en el procedimiento, de lo que se trata con la tipificación de esta falta es de evitar el riesgo de una actuación incorrecta ${ }^{81}$. El EBEP hace referencia ex-

78 En relación con esta cuestión el TS ha manifestado que ante todo "es necesario puntualizar que el deber de abstención del funcionario en las actividades legalmente incompatibles nace directamente de la ley no requiriendo en principio para su eficacia jurídica -con las eventuales consecuencias sancionadoras-, la mediación de una resolución del órgano administrativo competente. Está claro en el texto de la ley vigente (art. 14 de la Ley 53/1984) que el ejercicio por el funcionario de actividades profesionales, laborales, mercantiles o industriales fuera de las Administraciones Públicas requerirá el previo reconocimiento de compatibilidad. Es, pues, el ejercicio de la actividad extrafuncionarial lo que requiere la autorización del órgano administrativo y no dicha resolución la generadora del deber de abstención, independientemente de que al producirse resolución expresa, como es el caso que aquí se debate el deber de abstención queda reforzado por los efectos inherentes a la relación especial de sujeción existente entre la Administración y el funcionario".

79 Lafuentes Benaches, M., El régimen disciplinario de los funcionarios públicos de la Administración del Estado, op. cit., p. 77.

80 Art. 28.2 de la LPC.

81 Véase en este sentido, la Sentencia del TSJ de Galicia de 11 de noviembre de 1998 (RJ 4725) en la que se señala que ".... Precisamente para casos de vulneración del deber de imparcialidad como el de autos está prevista la sanción impuesta, sin que se requiera que en concreto los informes emitidos hayan sido incorrectos o desviados, ya que se trata de evitar el riesgo de que se produzca el favorecimiento, para lo que se obliga al funcionamiento a apartarse de intervenir en el procedimiento en el que esté interesada persona con la que tenga alguna vinculación de las que legalmente dan lugar al deber de abstención". 
presa a este deber de abstención en los artículos 53.5 (abstenerse en todos aquellos asuntos en los que tenga un interés personal), y 11 (abstenerse de todas aquellas conductas que comprometan la neutralidad en el ejercicio de los servicios públicos). En todo caso, para la realización del tipo será necesaria la existencia de dolo en la medida que el funcionario interviene en el procedimiento a sabiendas de que incurre en una de las causas de abstención legalmente previstas ${ }^{82}$. Desde el punto de vista de la responsabilidad penal, la no abstención en los casos legalmente exigibles no está tipificado como delito pero podría ser un "indicio decisivo para apreciar el delito de prevaricación o cohecho si, además del incumplimiento del deber de abstención, la resolución resultante es manifiestamente injusta o ha mediado precio o dádiva"83. Finalmente, cabe recordar que la falta de abstención, como es sabido, no siempre implica la nulidad del acto impugnado ${ }^{84}$.

\section{REFLEXIÓN FINAL}

La CE exige a la Administración pública y al personal que la integra un comportamiento objetivo, imparcial y neutral en el servicio al interés general. Estas reglas de actuación están previstas, a su vez, en el Código de Conducta contenido en el EBEP. Su fin principal es definir los deberes y principios que los empleados públicos deberán cumplir y respetar en el ejercicio de sus funciones. Sin embargo, esta relación de obligaciones, de reglas éticas y de conducta, integrantes del citado código, necesitan de la previsión y puesta en funcionamiento de un conjunto de medidas que garantice su cumplimiento. Así, la falta de imparcialidad y neutralidad del empleado público en el desempeño de su cargo contraviniendo con ello parte de las directrices que deben inspirar sus actuaciones conlleva, sin lugar a dudas, un reproche ético. La recriminación jurídica, sin embargo, ha de apoyarse, en primer término, en el derecho disciplinario que, como hemos visto, tipifica como infracción determinadas conductas de los empleados públicos que implican una vulneración del principio de objetividad. En segundo lugar, el ordenamiento jurídico articular, con el fin de evitar situaciones que pueden plantear al empleado público un conflicto de intereses, mecanismos de abstención y recusación, así como un sistema de incompatibilidades en garantía de su imparcialidad.

\section{BIBLIOGRAFÍA CITADA}

Almeida Cerreda, M., “La evaluación del desempeño de los empleados públicos. En particular, el establecimiento de sistemas de evaluación del desempeño en las Administraciones locales", Anuario de Derecho Municipal, n. ${ }^{\circ}$ 3, 2009.

82 También en este sentido Marina Jalvo, B., El régimen disciplinario de los funcionarios públicos, op. cit., p. 351.

83 Parada Vázquez, R., Régimen jurídico de las Administraciones Públicas y procedimiento administrativo común, Madrid: Marcial Pons, 1999, p. 142.

84 Sobre las consecuencias jurídicas de la no abstención puede verse el minucioso trabajo realizado por Doménech Pascual, G., “La abstención en el procedimiento administrativo”, op. cit., pp. 455 y ss. 
Arribas López, E., Sobre la vigencia del régimen disciplinario de los funcionarios después del Estatuto Básico del Empleado Público: "Interpretación mecanicista" versus “interpretación teleológica”, Revista General de Derecho Administrativo, n. ${ }^{\circ} 26,2011$.

Cámara del Portillo, D., Régimen disciplinario de los empleados públicos. La nueva regulación de la Ley 7/2007, de 12 de abril, del Estatuto Básico del Empleado Público, Madrid: Marcial Pons, 2008.

Carro Fernández Valmayor, J.L., “Ética pública y normativa administrativa”, Revista de Administración Pública, n. ${ }^{\circ}$ 181, 2010.

Castillo Blanco, F.A. y J. E. Quesada Lumbreras “Deberes de los empleados públicos. Código de Conducta", Comentarios a la Ley 7/2007, de 12 de abril, del Estatuto Básico del Empleado Público, dir. A. Palomar Olmeda y A.V. Sempere Navarro, Aranzadi, 2008.

Castillo Blanco, F.A., "Los deberes de los funcionarios públicos", Comentarios a la Ley del Estatuto Básico del Empleado Público, 2. ${ }^{a}$ Ed., dir. M. Sánchez Morón, Lex Nova, 2008.

Doménech Pascual, G., “La abstención en el procedimiento administrativo”, Nuevas perspectivas del Régimen Local. Estudios en Homenaje al Profesor José M. "Boquera Oliver, coord. J.M. Baño León y J. Climent Barberá, Valencia: tirant lo blanch, 2002.

Embid Irujo, A., La fidelidad de los funcionarios a la Constitución (Un estudio de los derechos alemán y español), Madrid: INAP, 1987.

Gárate Castro, J., “Art. 52. Deberes de los empleados públicos. Código de Conducta”, El Estatuto Básico del Empleado Público. Comentario sistemático de la Ley 7/2007, de 12 de abril de 2008, dir. J.L. Monereo Pérez et al, Granada: Comares, 2008.

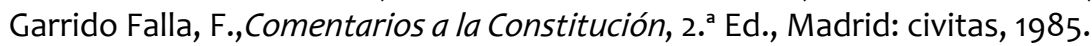

Malaret i García, E., “El Estatuto básico del empleado público, la modernización administrativa en el Estado de las Autonomías: un proceso en construcción", RVAP, n. ${ }^{\circ} 84,2009$.

González Pérez, J., y F. González Navarro, Comentarios a la Ley de Régimen Jurídico de las Administraciones Públicas y del Procedimiento Administrativo Común, Madrid: Civitas, 1999.

Lafuente Benaches, M., El régimen disciplinario de los funcionarios públicos de la Administración del Estado, Valencia: tirant lo blanch, 1996.

Maneiro Vázquez, Y., "Art. 53. Principios éticos”, El Estatuto básico del empleado público. Comentario sistemático de la Ley 7/2007, de 12 de abril de 2008, dir. J.L. Monereo Pérez, et al, Granada: Comares, 2008.

Marina Jalvo, B., El régimen disciplinario de los funcionarios públicos, 2. ${ }^{a}$ Ed., Valladolid: Lex Nova, 2001.

Martín Rebollo, L., Leyes Administrativas, 17 Ed., Aranzadi, 2011.

Miranda Boto, J.M., “Art. 54. Principios de conducta”, El Estatuto Básico del Empleado Público. Comentario sistemático de la Ley 7/2007, de 12 de abril de 2008, dir. J.L. Monereo Pérez et al, Granada: Comares, 2008.

Morell Ocaña, L., “La objetividad de la Administración Pública y otros componentes 208 de la ética de la institución”, REDA, n. ${ }^{\circ} 111,2001$. 
Nieto, A., “La Administración sirve con objetividad los intereses generales”, Estudios sobre la Constitución Española. Homenaje al Profesor Eduardo García de Enterría, Tomo III, Madrid:civitas, 1991.

Palomar Olmeda, A., Derecho de la Función Pública. Régimen Jurídico de los Funciona-

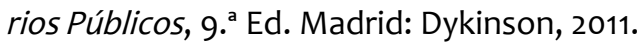

Parada Vázquez, R., Régimen jurídico de las Administraciones Públicas y procedimiento administrativo común, Madrid: Marcial Pons, 1999.

Parada Vázquez, R., Derecho Administrativo II. Organización y Empleo Público. Ed. 21, Madrid: Marcial Pons, 2010.

Quesada Lumbreras, J.E., “Título VII. Régiemen Disciplinario”El Estatuto básico del Empleado Público. Comentario sistemático de la Ley 7/2007, de 12 de abril de 2007, Dir. J.L. Monereo Pérez, et al, Granada: Comares, 2008.

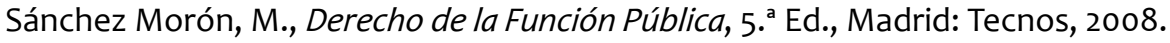

Sánchez Morón, M., "Régimen disciplinario", Comentarios a la Ley del Estatuto Básico del Empleado Público, 2. ${ }^{a}$ Ed., Valladolid: Lex Nova, 2008.

Santamaría Pastor, J.M., Principios de Derecho Administrativo General Il, Madrid:iustel, 2006.

Santamaría Pastor, J.A., Principios de Derecho Administrativo General l, 2. ${ }^{a}$ Ed., Madrid: lustel, 2009.

Sempere Navarro, A.V., y F.J. Hierro Hierro, "Título VII. Régimen disciplinario", Comentarios a la Ley 7/2007, de 12 de abril, del Estatuto Básico del Empleado Público, dir. A. Palomar Olmeda y A.V. Sempere Navarro, Aranzadi, 2008. 
